\title{
扁桃摘出術の術後管理とクリニカルパス \\ 梶川泰・成尾一彦* - 久保武・宮原裕* \\ The Usefulness of a Clinical Pathway for Patient Care Management Following Tonsillectomy
}

\author{
Hiroshi Kajikawa and Takeshi Kubo \\ (Osaka University Graduate School of Medicine) \\ Kazuhiro Nario and Hiroshi Miyahara \\ (Osaka Prefectural General Hospital)
}

\begin{abstract}
Recently, the use of clinical pathways has been introduced as a tool for improving medical quality in Japan. We applied a clinical pathway to the care management following tonsillectomy in adults and evaluated the outcome. In our pathway, sore throat, hemorrhage, diarrhea and fever elevation were the variables examined following tonsillectomy. For reduction of the level of these variables, in addition to our previous treatments, morphine was given at a dose of $20 \mathrm{mg}$ per day for 2 days following the operation, and pre-operative antibiotic therapy was introduced. As a result of these changes, we observed the decreased appearance of sore throat, diarrhea and fever elevation after tonsillectomy.
\end{abstract}

Key words : clinical pathway, tonsillectomy, morphine, pre-operative antibiotic therapy

\section{はじめに}

クリニカルパスは一定の疾患を持つ患者に対する検 查, 治療, 薬剤, 看護活動, 栄養指導, 安静度などを整 理統一し，順序だてて経時的にまとめたもので, Zander ${ }^{1)}$ によって考案された.クリニカルパスは看護の質の向上 のみならず, 患者の満足度の向上, 医療スタッフの教育, 医療施設の経営改善などに効果を上げている新しい医療 管理のツールで，近年わが国の医療現場へと導入されつ つある。 その本質的な特徴は, バリアンス（問題点）を 収集・分析することにより現在の治療内容や治療経過の どこに問題があるのかが明確になり, 容易に解決方法を 考え出すことができるなど, 医療の質改善へのフィード バックがシステムのなかに組み込まれていることであ る.また，入院の流れが統一されていることで，患者に 対して入院中の医療内容の説明が容易になり, 患者の疾
患に対する理解が深まるなどインフォームドコンセント の強力なツールになりらる.

口蓋扁桃摘出術は耳鼻咽喉科領域の小手術のなかで最 も一般的な手術の一つであり, 多数の医療機関で施行さ れている. しかし, その手術方法や術後管理は各施設, 各医師によってバラエティーに富んでいる，また，その 術後に生じる疼痛や出血に悩まされるケースが決して少 なくない，われわれはこれらに着目し，口蓋扁桃摘出術 の術後管理について再考するためにクリニカルパス（以 降パスとする）を導入した。

\section{対象}

対象は大阪府立急性期総合医療センター（旧：大阪府 立病院）耳鼻咽喉科において慢性扁桃腺炎で両側扁桃摘 出術を施行した症例（小児例は除く） 83 例である. 第 1

\footnotetext{
大阪大学大学院感覚器外科学耳鼻咽喉科

* 大阪府立急性期総合医療センター耳鼻咽喉科
} 
段階のパスを適応した対象は平成 12 年 1 月から 12 月ま での 34 例，年齢は $15 \sim 44$ 歳（平均 27 歳）で，第 2 段 階のパスを適応した対象は平成 13 年 1 月から 12 月まで の 49 例, 年齢は $15 \sim 50$ 歳（平均 28 歳）であった.

\section{方法}

大阪府立急性期総合医療センター耳鼻咽喉科で以前よ り施行されてきた口蓋扁桃摘出術の術後管理にそってパ スを作成し，これを第 1 段階の口蓋扁桃摘出術のパスと した. このパスを施行する過程で生じてきたバリアンス を収集，分析し，これらのバリアンスを解決するために 改変を行い第 2 段階のパスとした. さらにこの第 2 段階 のパスを施行, 分析して, 新たに導入した改変点を含め て検討を行った.

（1）第 1 段階のパス

術後の感染予防に抗生剂（FMOX 1g）を術後 2 日目ま で朝夕 1 日 2 回静脈内投与し, 3 日目より 5 日間経口抗 生剂を投与した. 疼痛コントロールとして経口薬として ポンタールシロップ ${ }^{\circledR} 1$ 回 $10 \mathrm{ml}$ 食前で, ボルタレン座 薬 ${ }^{\circledR} 25 \mathrm{mg}$ を屯用とした. また, 食事は手術当日に流動 食, 翌日より 3 分粥, 2 日目より 5 分粥, 4 日目より全粥 とした. 手術前日に入院し, 術後 8 日目で退院とした.

（2）第 2 段階のパス

第 1 段階のバリアンス分析をもとに塩酸モルヒネを $20 \mathrm{mg}$ /日でバクスター社製バクスターインヒューザー BB60を用いて術直後より 48時間持続静脈内投与し, 感染 予防の抗生剂は術直前に静脈内投与, 検查は術後 3 日目 に炎症反応（末血，CRP）の測定を追加した. 食事は主
食を術後 3 日目まで副食を術後 5 日目まで 5 分籷程度に 制限するなどの変更を行った。 また, 塩酸モルヒネを用 いず従来どおりポンタールシロップ® とボルタレン座 薬 ${ }^{\circledR}$ で疼痛コントロールを行らパスも作成しておき, 手 術前に前もって患者に説明しどちらのパスを用いるか患 者本人に選んでもらった.

\section{結果}

第 1 段階のバリアンス分析では摂食困難 $8.8 \%$, 嘔気 $5.8 \%$ ，下痢 $26 \%$ ，発熱 $\left(38.5^{\circ} \mathrm{C}\right.$ 以上） $5.8 \%$ ，再出血 (創部の凝血塊を形成するのみで処置を必要としないも のも含む） $11.7 \%$, 薬剤中止・変更 $35.3 \%$, 薬剤追加 26. $4 \%$ であった（図 1). また，術後に疼痛などで飲水困 難であったため補液を要した期間は 3 例を除いて全例が 術後 24 時間以内であった. さらに入院日数は平均術後 7 日であり, 術後 8 日目までにほぼ 9 割の症例が退院して いた.

第 2 段階では 3 例を除いた 46 例で塩酸モルヒネを用い たパスの使用を希望した. 1 例は喘息の既往があったた め，また 2 例は患者希望で塩酸モルヒネを用いないパス を使用した。塩酸モルヒネを用いた症例での主なバリア ンスは提食困難 $12.2 \%$, 嘔気 $28.5 \%$, 下痢 $8.1 \%$, 発熱 $\left(38.5^{\circ} \mathrm{C}\right.$ 以上) $8.1 \%$, 再出血（創部の凝血塊を形成する のみで処置を必要としないものも含む) $16.3 \%$, 薬剤中 止・変更 $18.3 \%$, 薬剤追加 $18.3 \%$ などであった（図 1 ). 第 1 段階と比較して改善されなかったのは摄食困難，嘔 気と再出血であった。このうち第 1 段階より悪化した嘔 気については性差が大きく嘔気を訴えた患者の $79 \%$ が女

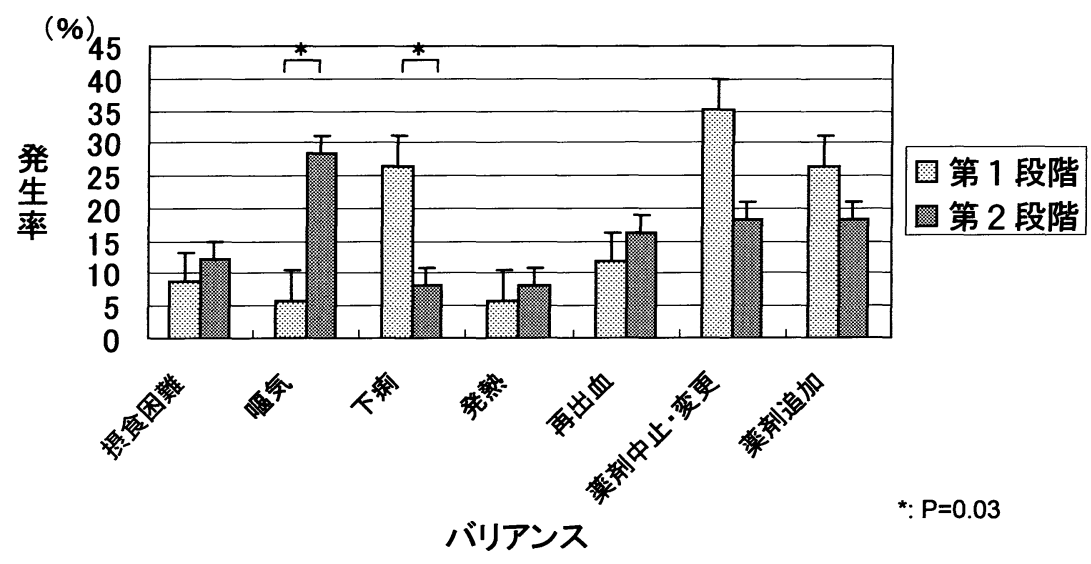

図 1 第 1 段階と第 2 段階の主なバリアンス発生状況 


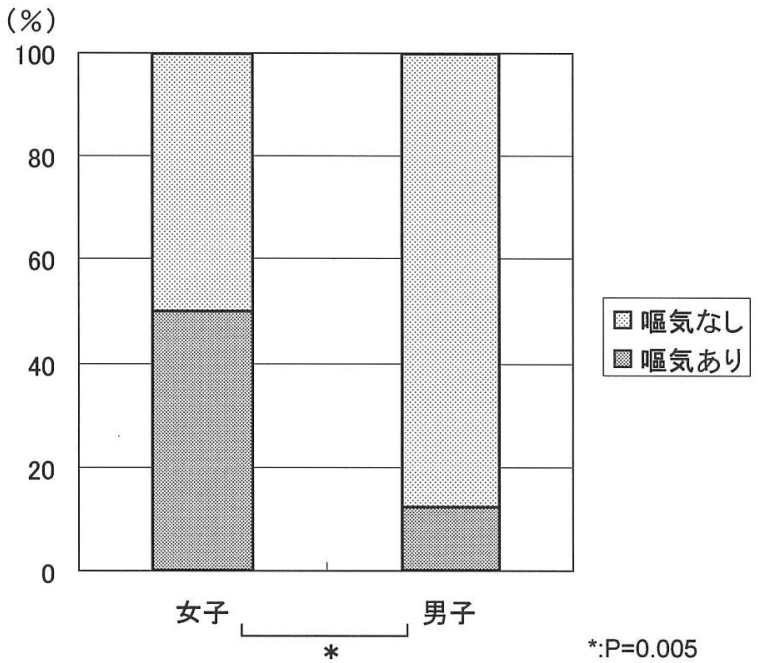

図 2 塩酸モルヒネによる嘔気の性差

性であった（図 2)。ボルタレン座薬®による疼痛コント ロールを必要とした症例は第 1 段階の $67 \%$ の症例，第 2 段階の $41 \%$ の症例であった（図 3 )。術後 3 日目の末血検 查では白血球は $6,000 \sim 8,000 / \mu 1$ が最も多く, 正常上限 は 10, 000/ $\mu 1$ 程度であった。また生化検查では CRP は 0 $\sim 2 \mathrm{mg} / \mathrm{dl}$ が最も多く正常上限は $4 \mathrm{mg} / \mathrm{dl}$ 程度であった。

\section{考察}

第 1 段階の主なバリアンスは扁桃摘出術特有の疼痛に よる摄食困難や苦悶様顔貌，下痢による薬剤中止・変更・ 追加, 術後感染発症によると考光られる $38.5^{\circ} \mathrm{C}$ 以上の 熱発，比較的高い頻度で生じる術後出血（処置を要しな い例む含む）であった，疼痛については以前よりアセ卜 アミノフェン，非ステロイド抗炎症薬（NSAIDs）などの

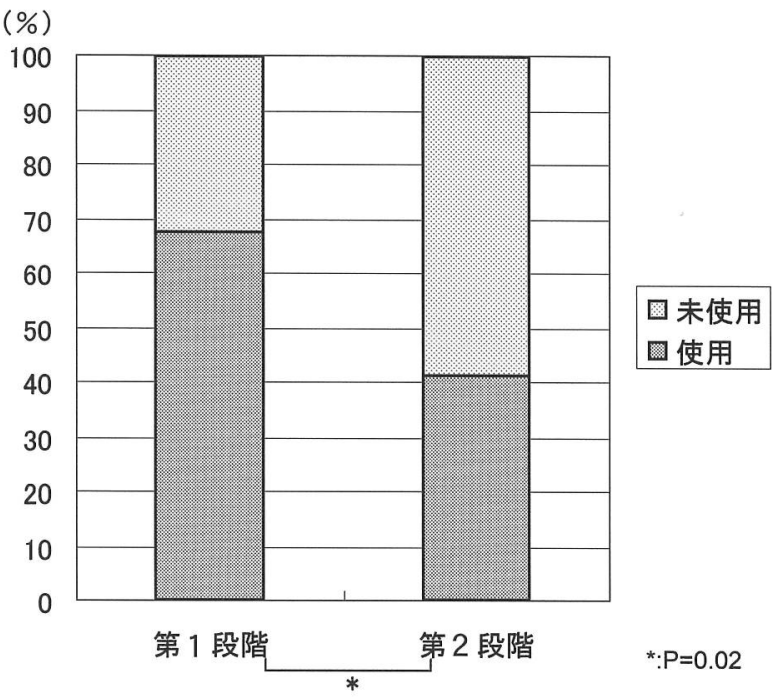

図 3 第 1 段階と第 2 段階でのボルタレン座薬 ${ }^{\circledR}$ の使用率

みでは疼痛をコントロールが不十分で，麻薬などのより 強力な鎮痛薬が必要であることが示唆されているこ と $^{2)}$, NSAIDs は扁桃摘出後の 2 次出血を増加させる可 能性が指摘されていること年4), 扁桃摘出後の塩酸モルヒ 亦使用の有効性が示唆されている5) ことなどから，われ われは第 2 段階のパスにおいて塩酸モルヒネを $20 \mathrm{mg} /$ 日 で術直後より持続点滴 48 時間行うことを試みた。また， 感染予防のために投与していた抗生剂を静脈内術前投与 とすることで感染予防の強化を期待し，さらに感染の状 況を把握するのに術後 3 日目に血液検査（末血，CRP） を行った（表 1 )。食事内容については第 1 段階では術後 日数にか力水らず患者希望に従い適宜全粥食や常食に変 更していたが，第 2 段階では術後出血の予防策として術

表 1 第 1 段階での問題点と第 2 段階での改善点

第 1 段階の問題点

- 疼痛

- 摂食困難や苦悶様顔貌

-下㾥

・下痢による薬剤中止・変更・追加

- 感染

$\cdot 38.5^{\circ} \mathrm{C}$ 以上の熱発

一術後出血（処置を要しない例も含む） ・退院日の遅延

\section{第 2 段階での改善点}

-塩酸モルヒネ（持続点滴）使用

$\cdot 20 \mathrm{mg} /$ 日で術後 2 日間

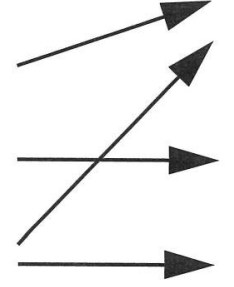

抗生剂の術前投与

一血液検査を術後 3 日目に実施

・食事の硬度を術後 3 日目までは 5 分䊀食まで, 術後 5 日目までは全 旛食までに制限 
後 3 日目までは 5 分强食までの硬度，術後 5 日目までは 全粥食（副食はキザミ食）までの硬度と食事の硬度を制 限するなどの変更を行い創部への安静をはかった。

モルヒネの導入によって術後の苦悶様顔貌はあまりみ られなくなり，術後のボルタレン座薬 ${ }^{\circledR}$ の使用量む低下 したことによく現れている（図 3)。鎮痛効果と鎮痛剤の 投与量で評価することは，担当看護師の判断と性格とい らバイアスがかかるが，術後の鎮痛㓮の投与が低下した のは痛みの訴えが少なかったからと判断される，術後に 生じていた下痢が $26 \%$ から $8 \%$ と有意に減少し，それに 伴う薬剤の中止・変更, 追加は減少することができた. 下痢の発症が抑制された要因の一つとして塩酸モルヒネ 投与により扁桃摘出後生じた術後性腸管運動六進が抑制 されたため考えられた. ところで，一般にモルヒネ投与 の合併症としては嘔気, 嘔吐が最も多く, 静脈内投与で は $17 \sim 66 \%$ で $50 \%$ 前後の報告が多い ${ }^{6)}$. 今回モルヒネ を使用しなかった第 1 段階に比べてモルヒネを使用した 第 2 段階では嘔気が $21.2 \%$ 増加，このうち嘔気を訴える 患者のほぼ 8 割が女性であり, これらはモルヒネの副作 用の特徴であると考えられた。 また，疼痛を抑制できた にもかかわらず術後の摄食困難が従来と比べ改善されな かったのもモルヒネによる嘔気のためと考えられる．た だ，嘔気はモルヒネを中止することで改善されることや 中止しても術後早期の持続的な咽頭痛を強力に制御する ことで中止後の疼痛の訴えはあまりないこと, 重篤な副 作用としての呼吸抑制は全症例で認められなかったこと などからも扁桃摘出後のモルヒネの投与は十分有効であ ると考えられた。このようなことからモルヒネによる嘔
気の発生を抑制しつつ疼痛効果をうるため現行の新しい パスではモルヒネ量を男性は $15 \mathrm{mg} /$ 日, 女性は $10 \mathrm{mg} /$ 日 に減量して施行中である.

扁桃摘出術は準污染手術とも感染手術とも考えられる 手術である。つまり手術に際しては準污染手術での術後 感染予防薬として, 感染手術での周術期に第 1 選択され

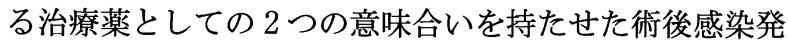
症治療薬といら概念7) で抗生剤が選択, 投与されなけれ ばならない。このようなことから第 2 段階では抗生剤の 術前投与をさらに追加したが術後の発熱の状況には目 立った変化はなかった。 しかし, 扁桃摘出術後の抗生剤 投与については鎮痛効果，熱発の抑制，経口攝取，術後 の活動性の項目で有効性が証明されていること ${ }^{899)}$ と CDC のガイドライン ${ }^{10)}$ 双方の考え方を踏まえて, 積極的 に術前抗生剂投与を行い，術後は経口摂取が可能であれ ば静脈内投与を早期に中止し，経口抗生剂に変更してい きたいと考えている. ところで, 術後 3 日目の時点の炎 症反応の測定結果から白血球数とCRPの上限はそれぞれ $10000 / \mu 1$ と $4 \mathrm{mg} / \mathrm{dl}$ 程度と考えられた（図 4). 術後 3 日 目以降で発熱を認め白血球数またはCRPがこの上限を超 えれば術後感染を発症したと考えられ，治療的抗生剤の 追加, 変更などの何らかの追加加療を考慮する必要が生 じてくると考えられた。

扁桃摘出術では術後の出血のコントロールが重要であ る. 術後出血には術後 24 時間以内に起こる 1 次性出血と それ以降の 2 次性出血に分類される. 今回の出血のうち 実際に処置を要するような出血は 5 例でこのうち 1 次性 出血は 3 例 $3.6 \%, 2$ 次性出血は 2 例 $2.4 \%$ であった。 こ

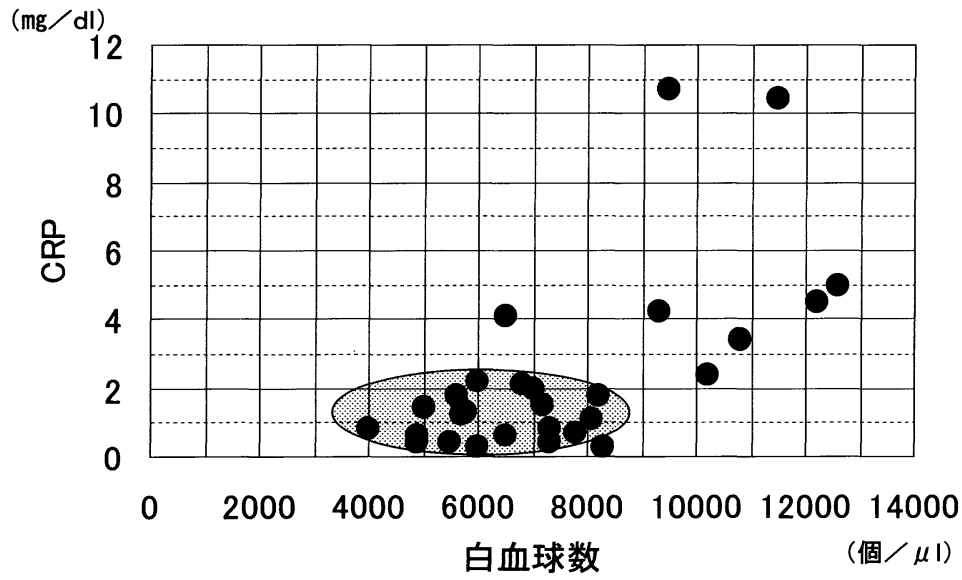

図 4 術後 3 日目の炎症反応 
れは行木 ${ }^{11)}$ の報告で 1 次性の術後出血が扁桃摘出症例 1047 例中 33 例 $3.3 \%$ としているのとほぼ一致している. さらに術後少なからず凝血塊を生じているような軽度出 血例を含めると $10 \%$ 程度に上った. 第 2 段階では術後出 血リスクを少しでも軽減できるよう術後食の硬度を制限 する工夫をしてみたが出血率に変化はなかったので術後 出血と食事はあまり関連しないと考えられた. ところで 本邦において扁桃摘出後の最も一般的な鎮痛剤は非ステ ロイド性消炎鎮痛剂である。これは強力な血小板の凝集 能抑制作用を有しており, Smith ら² によると NSAIDsを 処方された 217 例中 24 例 $(11 \%)$ に 次性出血がみられ たのに対し，処方されていない 340 例中 5 例 (1.5\%) で あったとしていることから NSAIDs は 2 次性出血を増加 させる可能性が高くなるとしている．次回のパスからは 扁桃摘出後の食事は患者希望にあわせた硬度でよいこと とし，できれば疼痛コントロールにアセトアミノフェン などの血小板凝集抑制のきわめて少ない鎮痛剤をモルヒ ネの補助薬として使用することを検討している4).

\section{まとめ}

今回，扁桃摘出術後のパスを運用することで，日頃の 術後管理の盲点が明らかになり，塩酸モルヒネによる疼 痛管理や術前抗生剤投与による術後感染制御などの新し い治療を試み，効果をあげることが可能となった。 今後 もパスのフィードバックシステムを利用し扁桃摘出術だ けでなく他の耳鼻咽喉科疾患についても EBM にのっ とった質の高い医療を目指していきたいと考えている.

\section{謝 辞}

稿を終わるにあたり多大なご協力をいただいた大阪府立急性 期総合医療センター9 階西病棟のクリニカルパスチームのス タッフに深謝いたします。

\section{参考文献}

1) Zander K : Critical pathways. The Health Care Pioneers (ed by
Melum MM and Sinicris MK). pp $305 \sim 314$, American Hospital Publishing Inc, Chicago, 1992.

2) Rusy LM, Houck CS, Sullivan LJ, et al. : A double-blind evaluation of ketorolac tromethamine versus acetaminophen in pediatric tonsillectomy: analgesia and bleeding. Anesth Analg 80 : $226 \sim 229,1995$.

3) Smith I and Wilde A : Secondary tonsillectomy hemorrhage and non-steroidal anti-inflammatory drugs. J Laryngol Otol $113: 28 \sim 30,1999$.

4) April MM and Naclerio RM : Complications of tonsillectomy and adenoidectomy. Complications in Head and Neck Surgery (ed by Eisele DW). pp $262 \sim 266$, Mosby, St Louis, 1993.

5）新堀博展, 三輪高明, 広木公一：小児の扁桃摘出術後の鎮 痛に塩酸モルヒネを用いた Patient-controlled analgesia の有 効性の検討. こども医療 $32: 40 〜 42,2003$.

6) Hirayama T, Ishii F, Yago K, et al. : Evaluation of the effective drugs for the prevention of nausea and vomiting induced by morphine used for post-operative pain: a quantative systemic review. Yakugaku Zasshi $121: 179 \sim$ 185, 2001.

7）日本化学療法学会臨床評価法制定委員会術後感染予防委員 会 : 術後感染発症阻止抗菌薬の臨床評価に関するガイドラ イン（1997 年度版）. 日化療会誌 $45: 553 \sim 641,1997$.

8) Telian SA, Handler SD, Fleisher GR, et al. : The effect of antibiotic therapy on recovery after tonsillectomy in children: a controlled study. Arch Otolaryngol Head Neck Surg $112: 610$ $\sim 615,1986$.

9) Grandis JR, Johnson JT, Vickers RM, et al. : The effect of preoperative antibiotic therapy on recovery following tonsillectomy in adults: randomized double-blind placebo-control trial. Otolaryngol Head Neck Surg $106: 137 \sim$ 142, 1992.

10）大久保憲, 小林寛伊（訳）：手術部位感染防止ガイドライ ン, 1999. 手術医学 $20: 297,1999$.

11）行木英生: 咽頭手術の術後管理. JOHNS 3:614 618, 1987.

原稿受付 : 平成 16 年 3 月 22 日

原稿採択：平成16年 5 月 26 日

別刷請求先：梶川 泰

于565-0871 大阪府吹田市山田丘2-2

大阪大学大学院医学系研究科 (E8) 感覚器外科学耳鼻 咽喉科 